\title{
Chicken Pox
}

National Cancer Institute

\section{Source}

National Cancer Institute. Chicken Pox. NCI Thesaurus. Code C97132.

A contagious childhood disorder caused by the varicella zoster virus. It is transmitted via respiratory secretions and contact with chickenpox blister contents. It presents with a vesicular skin rash, usually associated with fever, headache, and myalgias. The pruritic fluid-filled vesicles occur 10-21 days after exposure and last for 3-4 days. An additional 34 days of malaise follows before the affected individual feels better. An individual is contagious 1-2 days prior to the appearance of the blisters until all blisters are crusted over. Generally, healthy individuals recover without complications. 